Corresponding author: V.V. Atuchin

Institute of Semiconductor Physics, Novosibirsk 630090, Russia

Fax: +7 (383) 3332771

E-mail: atuchin@isp.nsc.ru

\title{
Structural and spectroscopic properties of self-activated monoclinic molybdate
}

\section{$\mathrm{BaSm}_{2}\left(\mathrm{MoO}_{4}\right)_{4}$}

V.V.Atuchin ${ }^{1,2,3,4}$, A.S. Aleksandrovsky ${ }^{5,6}$, M.S. Molokeev ${ }^{7,8,9}$, A.S. Krylov ${ }^{10}$, A.S. Oreshonkov ${ }^{10,11}$, Di Zhou ${ }^{12,13}$

${ }^{1}$ Laboratory of Optical Materials and Structures, Institute of Semiconductor Physics, SB RAS, Novosibirsk 630090, Russia

${ }^{2}$ Functional Electronics Laboratory, Tomsk State University, Tomsk 634050, Russia

${ }^{3}$ Laboratory of Semiconductor and Dielectric Materials, Novosibirsk State University, Novosibirsk 630090, Russia

${ }^{4}$ Laboratory of Single Crystal Growth, South Ural State University, Chelyabinsk 454080, Russia

${ }^{5}$ Laboratory of Coherent Optics, Kirensky Institute of Physics, Federal Research Center KSC SB RAS, Krasnoyarsk 660036, Russia

${ }^{6}$ Laboratory for Nonlinear Optics and Spectroscopy, Siberian Federal University, Krasnoyarsk 660041, Russia

${ }^{7}$ Laboratory of Crystal Physics, Kirensky Institute of Physics, Federal Research Center KSC SB RAS, Krasnoyarsk 660036, Russia

${ }^{8}$ Department of Physics, Far Eastern State Transport University, Khabarovsk 680021, Russia ${ }^{9}$ Siberian Federal University, Krasnoyarsk 660079, Russia 
${ }^{10}$ Laboratory of Molecular Spectroscopy, Kirensky Institute of Physics, Federal Research Center KSC SB RAS, Krasnoyarsk 660036, Russia

${ }^{11}$ Department of Photonics and Laser Technologies, Siberian Federal University, Krasnoyarsk 660079, Russia

${ }^{12}$ Electronic Materials Research Laboratory, Key Laboratory of the Ministry of Education \& International Center for Dielectric Research, Xi'an Jiaotong University, Xi’an 710049, Shaanxi, China

${ }^{13}$ Materials Science and Engineering, University of Sheffield, Sheffield, S1 3JD, UK

\begin{abstract}
The crystal structure of new monoclinic molybdate $\mathrm{BaSm}_{2}\left(\mathrm{MoO}_{4}\right)_{4}$ is refined in monoclinic unit cell $C 2 / m$ with cell parameters $a=5.29448 \AA, b=12.7232 \AA, c=19.3907 \AA, \beta=91.2812^{\circ}, V=1305.89$ $\AA^{3}$. The crystal structure consists of the $\mathrm{SmO}_{8}$ square antiprism joined with each other by the edges forming a $2 \mathrm{D}$ layer perpendicular to the $c$-axis. $\mathrm{MoO}_{4}$ tetrahedra join $\mathrm{SmO}_{8}$ by nodes and also participate in layer formation, and $\mathrm{Ba}$ ions are located between these layers. The lattice dynamics is theoretically calculated on the base of the crystal structure data. The Raman spectra are recorded and analyzed in comparison with theoretical calculations. The discrepancy between the experimental and calculated Raman frequencies does not exceed $2 \mathrm{~cm}^{-1}$ for the most of Raman lines. The luminescence spectra of $\mathrm{Sm}^{3+}$ ions, which are positioned in the lowest local symmetry site $C_{1}$, strongly differ from those detected for another molybdate crystal, $\beta-\mathrm{RbSm}\left(\mathrm{MoO}_{4}\right)_{2}$, with the $C_{2}$ local symmetry. The ${ }^{4} \mathrm{G}_{5 / 2} \rightarrow{ }^{6} \mathrm{H}_{9 / 2}$ band is dominating in the $\mathrm{BaSm}_{2}\left(\mathrm{MoO}_{4}\right)_{4}$ luminescence.
\end{abstract}

Keywords: synthesis; crystal structure; coordination; SEM; Raman; luminescence

\title{
1. Introduction
}


Presently, materials based on the crystalline structure of various rare-earth-containing molybdates are under extensive study in connection with a number of applications including solidstate lighting [1-7], upconverting phosphors ([9,10] and references therein), energy storage [11], microwave electronics [12-14], catalysis [15,16], laser and stimulated Raman scattering media $[17,18]$, etc. The crystal structure of multicationic molybdates can exhibit a number of structural features, such as polymorphism, incommensurate modulation, structure-inferred vacancies, ionic occupation disorder, as well as the possibility of controlling the local environment of rare-earth ions by varying the nomenclature and content of additional ions [19-22]. The latter is of importance for the optical properties of rare-earth ions, such as distribution of absorption cross-sections and luminescence intensities between different bands, as well as the shapes of these bands proper, due to a strong influence of crystal field on the probabilities of $f$ - $f$ transitions and the energy structure of crystal-field-split sublevels. Another important factor that affects the optical properties of rareearth ions in crystalline matrices is the interaction between electronic excitations and vibrational modes; this interaction influences the radiativeless relaxation processes that decrease the luminescence intensities and change the distribution of excited states populations. Finally, different matrices may favor the dipole-dipole energy transfer between ions to a larger or smaller extent that, in particular, influences the luminescence concentration quenching. For instance, the monoclinic $\alpha$ $\mathrm{Eu}_{2}\left(\mathrm{MoO}_{4}\right)_{3}$ crystal was found to exhibit rather strong $\mathrm{Eu}^{3+}$ ion luminescence indicating a weaker concentration quenching than in other highly concentrated crystals [23,24].

In the present paper, the crystal structure, luminescence and Raman spectra of new monoclinic molybdate crystal $\mathrm{BaSm}_{2}\left(\mathrm{MoO}_{4}\right)_{4}$ are investigated. Earlier, a similar crystal structure was reported for $\mathrm{BaNd}_{2}\left(\mathrm{MoO}_{4}\right)_{4}[25]$, and, recently, the microwave properties of $\mathrm{BaSm} 2\left(\mathrm{MoO}_{4}\right)_{4}$ ceramics were elucidated [12]. However, the structural and spectroscopic properties of this crystal remain unknown.

\section{Experimental}


The $\mathrm{BaSm}_{2}\left(\mathrm{MoO}_{4}\right)_{4}$ ceramic samples were prepared via the solid state reaction method using $\mathrm{BaCO}_{3}, \mathrm{Sm}_{2} \mathrm{O}_{3}$ and $\mathrm{MoO}_{3}(>99 \%)$ as initial materials. The calcination temperature was $700{ }^{\circ} \mathrm{C}$ and the sintering temperature $-960{ }^{\circ} \mathrm{C}$. More details can be found in our previous work [12]. Ceramic microstructures were observed on the as-fired surface with scanning electron microscopy (SEM) (JSM-6460, JEOL, Tokyo, Japan).

The powder diffraction data of $\mathrm{BaSm}_{2}\left(\mathrm{MoO}_{4}\right)_{4}$ for Rietveld analysis were collected at room temperature with a Bruker D8 ADVANCE powder diffractometer $(\mathrm{Cu} \mathrm{K \alpha}$ radiation) and linear VANTEC detector. The step size of $2 \theta$ was $0.016^{\circ}$ and the counting time was 2 s per step. The $2 \theta$ range of $5-70^{\circ}$ was measured with the $0.6 \mathrm{~mm}$ divergence slit, but the $2 \theta$ range of $70-140^{\circ}$ was measured with the $2 \mathrm{~mm}$ divergence slit. Larger slits allow a noticeably increase in high-angle peaks intensity without a loss of resolution because the high-angle peaks are broad enough to be not affected by a bigger divergence beam. The esd's $\sigma\left(I_{\mathrm{i}}\right)$ of all points on the patterns were calculated using intensities $I_{\mathrm{i}}: \sigma\left(I_{\mathrm{i}}\right)=I_{\mathrm{i}}{ }^{1 / 2}$. The intensities and obtained esd's were further normalized: $I_{\mathrm{i} \text { norm }}=$ $I_{\mathrm{i}} \times 0.6 /($ slit width $), \sigma_{\text {norm }}\left(I_{\mathrm{i}}\right)=\sigma\left(I_{\mathrm{i}}\right) \times 0.6 /($ slit width $)$, taking into account the actual value of the divergence slit width which was used to measure each particular intensity $I_{\mathrm{i}}$, and that saved in the xye-type file. So, the transformed powder pattern has a common view in the whole $2 \theta$ range of 5 $140^{\circ}$, but all high-angle points have small esd values.

The luminescence spectra were recorded under the excitation at $355 \mathrm{~nm}$ using a DPSS frequency-tripled Nd:YAG LaserCompact LCS-DTL-374QT laser and an LOMO DFS-24 spectrometer. The unpolarized Raman spectra were collected in a backscattering geometry using a triple monochromator Horiba Jobin Yvon T64000 Raman spectrometer operating in an subtractive mode. The spectral resolution for the recorded Stokes side Raman spectra was set to $\sim 4 \mathrm{~cm}^{-1}$ (this resolution was reached by using gratings with 1800 grooves $/ \mathrm{mm}$ and $100 \mathrm{~mm}$ slits). The microscope system based on an Olympus BX41 microscope with an Olympus $50^{\mathrm{x}}$ objective lens $f=$ $0.8 \mathrm{~mm}$ with $\mathrm{NA}=0.75$ numerical aperture provides a focal spot diameter of about $2 \mu \mathrm{m}$ on the sample [26,27]. Single-mode argon, $514 \mathrm{~nm}$ from a Spectra-Physics Stabilite $2017 \mathrm{Ar}^{+}$laser of 3 
$\mathrm{mW}$ on the sample, was used as an excitation light source. The laser light intensity was adjusted to avoid the sample heating. The spectral lines positions and widths were obtained by the least square fitting of the experimental data to the Lorentzian equation [28]:

$$
I_{L}=\frac{A}{1+\left(\frac{x-\omega}{\Gamma}\right)^{2}}
$$

where $A$-amplitude, $\omega$-wavenumber, $\Gamma$-full width at a half height, and $x$-actual coordinate (wavenumber).

\section{Results and discussions}

The XRD pattern recorded from the $\mathrm{BaSm}_{2}\left(\mathrm{MoO}_{4}\right)_{4}$ sample is shown in Fig. 1. The Rietveld refinement of $\mathrm{BaSm}_{2}\left(\mathrm{MoO}_{4}\right)_{4}$ XRD data was performed by using TOPAS 4.2 [29] which accounts esd's of each point by a special weight scheme. All peaks were indexed by the monoclinic cell $(C 2 / c)$ with the parameters close to those of $\mathrm{BaNd}_{2}\left(\mathrm{MoO}_{4}\right)_{4}[25]$ and, therefore, the crystal structure of $\mathrm{BaNd}_{2}\left(\mathrm{MoO}_{4}\right)_{4}$ was taken as a starting model for Rietveld refinement. However, the nonstandard space group $B 2 / b$ used in Ref. 25 was transformed into standard setting $C 2 / c$, and all catom oordinates were transformed accordingly. The $\mathrm{Nd}^{3+}$ ion site was occupied by $\mathrm{Sm}^{3+}$ ion. In order to reduce the number of refined parameters, only one thermal parameter was refined for all $\mathrm{O}$ atoms. The refinement was stable and gave low R-factors (Table 1, Fig.1). The atom coordinates and main bond lengths are summarized in Tables S1 and S2, respectively.

The crystal structure consists of $\mathrm{SmO}_{8}$ square antiprisms joined with each other by the edges forming 2D layers perpendicular to the $c$-axis, as shown in Fig. 2. The $\mathrm{MoO}_{4}$ tetrahedra join $\mathrm{SmO}_{8}$ by nodes and also participate in the formation of the layers and $\mathrm{Ba}^{2+}$ ions are located between these layers. Namely, such layered crystal structure leads to the interesting effect of changing cell parameters due to the $\mathrm{Sm}^{3+} \rightarrow \mathrm{Nd}^{3+}$ ion replacement. As far as ion radius $\operatorname{IR}\left(\mathrm{Nd}^{3+}, \mathrm{CN}=8\right)=1.109$ $\AA$ is bigger that $\operatorname{IR}\left(\mathrm{Sm}^{3}, \mathrm{CN}=8\right)=1.079 \AA$, the cell volume of $\operatorname{BaNd}_{2}\left(\mathrm{MoO}_{4}\right)_{4}\left(V=1323.22 \AA^{3}\right)$ [25] is predictably bigger than the cell volume of $\mathrm{BaSm}_{2}\left(\mathrm{MoO}_{4}\right)_{4}\left(V=1305.89\right.$ (2) $\left.\AA^{3}\right)$. But only $a$ 
and $b$ cell parameters are responsible for the change of this cell volume: $\delta a=0.64 \%, \delta b=0.63 \%$, $\delta c=0.03 \%$. Cell parameter $c$ stays almost invariable, but the relative changes of $a, b$ parameters are noticeable and similar in magnitude. This is because substitution $\mathrm{Sm}^{3+} \rightarrow \mathrm{Nd}^{3+}$ leads to the enlargement of the 2D layer only. However, the distance between the layers is governed by the $\mathrm{Ba}^{2+}$ ion size (Fig. 2). Further comparison of cell parameters $\mathrm{BaSm}_{2}\left(\mathrm{MoO}_{4}\right)_{4}$ and $\mathrm{BaYb}_{2}\left(\mathrm{MoO}_{4}\right)_{4}$ [30] also show the similar behavior: $\delta a=2.13 \%, \delta b=2.01 \%, \delta c=0.21 \%$. Therefore, the cell parameter deformations can be predictable and controlled by different ions $\mathrm{A}, \mathrm{Re}$ in the formula of $\mathrm{ARe}_{2}\left(\mathrm{MoO}_{4}\right)_{4}$.

Further details of the crystal structure may be obtained from Fachinformationszentrum Karlsruhe, 76344 Eggenstein-Leopoldshafen, Germany (fax: (+49)7247-808-666; E-mail: crystdata@fiz-karlsruhe.de; http://www.fiz-karlsruhe.de/request_for_deposited_data.html on quoting the deposition number CSD-432954.

The SEM pattern is shown in Fig. 3 [12]. As it is evident, the sample bulk is formed by closely packed well faceted plate-like microcrystals with a length of $2-5 \mu \mathrm{m}$ and $\sim 1 \mu \mathrm{m}$ in thickness. The temperature of $960{ }^{\circ} \mathrm{C}$ is in the range of molybdenum oxide active sublimation in the air environment, and this process stimulates the material exchange during the molybdates synthesis that results in the formation of microcrystals with equilibrial shapes and atomically flat facets $[23,31,32]$.

The Raman spectrum recorded from the $\mathrm{BaSm}_{2}\left(\mathrm{MoO}_{4}\right)_{4}$ powder is shown in Fig. 4. About 40 narrow Raman lines were revealed by the experimental spectrum fitting, and the complete set of Raman lines found in $\mathrm{BaSm}_{2}\left(\mathrm{MoO}_{4}\right)_{4}$ is shown in Table 4. The Raman spectrum of $\mathrm{BaSm} 2\left(\mathrm{MoO}_{4}\right)_{4}$ can be divided into two parts with a wide empty gap of $500-700 \mathrm{~cm}^{-1}$ that is commonly observed in the molybdates with $\mathrm{MoO}_{4}$ tetrahedra [33-41]. The extended spectra with component decomposition in the low and high wavenumber ranges are shown in Figs. $1 \mathrm{~S}$ and $2 \mathrm{~S}$. In the range of stretching vibrations of $\mathrm{MoO}_{\mathrm{n}}$ polyhedra $\left(\mathrm{n}=4\right.$ or $\left.6,720-940 \mathrm{~cm}^{-1}\right)$, a lot of lines were observed. The most 
intensive line is detected at $950.2 \mathrm{~cm}^{-1}$. The Raman spectra obtained under excitation at 514.5 and $488 \mathrm{~nm}$ are shown comparatively in Fig. 3S.

The vibrational representation for the monoclinic phase at the Brillouin zone center is:

$$
\Gamma_{\text {vibr }}=34 A_{g}+34 A_{u}+34 B_{g}+35 B_{u}
$$

acoustic and optic modes: $\Gamma_{\text {acoustic }}=A_{u}+2 B_{u}, \Gamma_{\text {optic }}=34 A_{g}+33 A_{u}+34 B_{g}+33 B_{u}$;

infrared and Raman active modes: $\Gamma_{\text {raman }}=34 A_{g}+34 B_{g}, \Gamma_{\text {infrared }}=33 A_{u}+33 B_{u}$.

To calculate the $\mathrm{BaSm}_{2}\left(\mathrm{MoO}_{4}\right)_{4}$ vibrational spectrum, the program package LADY was used [42]. The atomic vibration values were obtained using the simplified version of the Born-Karman model [43]. Within this model, only the pair-wise interactions and bond-stretching force constants $F$ are considered and the model implies that $F$ depends on $r_{i j}$ (interatomic distance) and the $F\left(r_{i j}\right)$ functions are the same for all atom pairs: $F\left(r_{i j}\right)=\lambda \exp \left(-r_{i j} / \rho\right)$, where $\lambda$ and $\rho$ are the parameters characterizing the selected pair interaction. To find the model parameters, the special optimization program was written and tested for several compounds [10, 23, 44-57]. The crystal lattice stability conditions were taken into account. The parameters finally obtained for $\mathrm{BaSm}_{2}\left(\mathrm{MoO}_{4}\right)_{4}$ are shown in Table 1S.

The calculations show that 52 Raman-active modes are possible in the range of $<500 \mathrm{~cm}^{-1}$. Besides, 1 mode around $500 \mathrm{~cm}^{-1}$ and 16 Raman-active modes should appear in the range of $>700$ $\mathrm{cm}^{-1}$. This is in agreement with the selection rules, and the calculated parameters of 69 possible Raman active modes are summarized in Table 4 in comparison with experimental results.

The strong high-wavenumber band at $950.2 \mathrm{~cm}^{-1}$ is assigned to the Mo2-O7 bond stretching vibration (Mo-O bond with the shortest length in $\left.\mathrm{BaSm}_{2}\left(\mathrm{MoO}_{4}\right)_{4}\right)$, as shown in Fig. 5(a). The next one strong peak at $925 \mathrm{~cm}^{-1}$ is the Mo1 - O2 bond stretching vibration. The band at $890 \mathrm{~cm}^{-}$ ${ }^{1}$ corresponds to the $\mathrm{O} 1-\mathrm{Mo} 1-\mathrm{O} 3$ antisymmetric stretching vibration depicted in Fig. 5(b). The strong band at $854 \mathrm{~cm}^{-1}$ is a symmetric stretching vibration of $\mathrm{O} 1, \mathrm{O} 2$ and $\mathrm{O} 3$ atoms towards Mo1, 
as shown in Fig. 5(c). The relatively weak bands at 802 and $753 \mathrm{~cm}^{-1}$ are $v_{3}$ vibrations [58] of Mo2 and Mo1 tetrahedra, correspondingly. Because the Mo1 - O5 bond length is longer than other bonds in Mo1 tetrahedra by more than $0.13 \AA$, the wavenumber of the corresponding vibration descended in the region of $713 \mathrm{~cm}^{-1}$ (Fig. 5(d)). According to the lattice dynamics simulation, the vibration of the oxygen bridge between Mo1 tetrahedra (Fig. 5(e)) should appear in Raman spectra in the region of about $500 \mathrm{~cm}^{-1}$, and this vibration, probably, can be observed in Raman spectra at low temperature [59]. The Raman lines over the $270-420 \mathrm{~cm}^{-1}$ range are related to $\mathrm{MoO}_{4}$ bending modes. Generally, the frequency of $v_{4}$ vibration should be above that of the $v_{2}$ vibration [58], and our calculation results are in agreement with this relation. The region of $200-260 \mathrm{~cm}-1$ is a region of rotational vibrations of the tetrahedral group. As to the low wavenumber range of $40-200 \mathrm{~cm}^{-1}$, this region contains the external vibrations of $\mathrm{MoO}_{4}$ units, translational and mixed with the $\mathrm{MoO}_{4}$ vibrations of $\mathrm{Ba}$ and $\mathrm{Sm}$ ions.

The luminescence spectra of $\mathrm{BaSm}_{2}\left(\mathrm{MoO}_{4}\right)_{4}$ were recorded under the excitation at wavelengths 355,488 and $514.5 \mathrm{~nm}$. The radiation at $355 \mathrm{~nm}\left(28200 \mathrm{~cm}^{-1}\right)$ falls into the absorption bands at the transitions from the $\mathrm{Sm}^{3+}$ ground state ${ }^{6} \mathrm{H}_{5 / 2}$ to a number of closely spaced high-lying states, most probably, to ${ }^{4} \mathrm{H}_{7 / 2}$. The radiation at $488 \mathrm{~nm}\left(20500 \mathrm{~cm}^{-1}\right)$ excites another group of closely lying excited states, most probably, ${ }^{4} \mathrm{I}_{9 / 2}$. The radiation at $514.5 \mathrm{~nm}\left(19430 \mathrm{~cm}^{-1}\right)$ is not in good resonance with samarium absorption bands. The $355 \mathrm{~nm}$ excited luminescence of $\mathrm{BaSm}_{2}\left(\mathrm{MoO}_{4}\right)_{4}$ ceramic sample (thick red line), in comparison with another molybdate, $\beta-\mathrm{RbSm}\left(\mathrm{MoO}_{4}\right)_{2}$ (blue thin line), used as the reference sample [60], is shown in Fig. 6.

As evident from Fig. 6, the luminescence of $\mathrm{BaSm}_{2}\left(\mathrm{MoO}_{4}\right)_{4}$ ceramic is found to be weaker than that of $\beta-\mathrm{RbSm}\left(\mathrm{MoO}_{4}\right)_{2}$ powder, and recording its spectrum required a larger slit width. There is a strong difference between the distributions of luminescence bands' intensities in $\mathrm{BaSm}_{2}\left(\mathrm{MoO}_{4}\right)_{4}$ and $\beta-\operatorname{RbSm}\left(\mathrm{MoO}_{4}\right)_{2}$. Three main luminescent bands are observed for $\mathrm{BaSm}_{2}\left(\mathrm{MoO}_{4}\right)_{4}$, all of them starting from the ${ }^{4} \mathrm{G}_{5 / 2}$ state. The maximum luminescence band of $\mathrm{BaSm}_{2}\left(\mathrm{MoO}_{4}\right)_{4}$ corresponds to the ${ }^{4} \mathrm{G}_{5 / 2} \rightarrow{ }^{6} \mathrm{H}_{9 / 2}$ transition, while, in the reference sample, we observed the absolute domination of 
the ${ }^{4} \mathrm{G}_{5 / 2} \rightarrow{ }^{6} \mathrm{H}_{5 / 2}$ transition terminating at the ground state of samarium ion. Evidently, the difference noted above is connected with the different local symmetry of samarium in the crystal structure under study and in the reference $\mathrm{RbSm}\left(\mathrm{MoO}_{4}\right)_{2}$ structure. In both crystals, the samarium ion is surrounded by 8 neighboring oxygen ions. However, its local symmetry in $\mathrm{BaSm}_{2}\left(\mathrm{MoO}_{4}\right)_{4}$ is $C_{1}$, while, in the reference crystal, the local symmetry is $C_{2}$ and it can be associated with a strongly distorted cubic antiprism. That strong distortion is the origin of specific spectral distribution of the luminescence in the $\mathrm{RbSm}\left(\mathrm{MoO}_{4}\right)_{2}$ reference crystal [60]. The local environment of samarium in $\mathrm{BaSm}_{2}\left(\mathrm{MoO}_{4}\right)_{4}$ can hardly be associated with any kind of distortion of a regular polyhedron (Fig. 7).

On the other hand, the spectral distribution of the luminescence in $\mathrm{BaSm}_{2}\left(\mathrm{MoO}_{4}\right)_{4}$ is somehow closer to a traditional one, for instance in most of $\mathrm{Sm}^{3+}$-bearing glasses. The local environment of samarium in glasses is formed mainly by the chemical properties of samarium proper; this local environment is the result of the minimum of interaction potential energy that is attained during the time of glassy structure formation. The Judd-Ofelt parameters of samarium in different glassy matrices are rather close to each other [61]. Typically, in glasses, the ${ }^{4} \mathrm{G}_{5 / 2} \rightarrow{ }^{6} \mathrm{H}_{7 / 2}$ transition dominates in the luminescence while ${ }^{4} \mathrm{G}_{5 / 2} \rightarrow{ }^{6} \mathrm{H}_{5 / 2}$ and ${ }^{4} \mathrm{G}_{5 / 2} \rightarrow{ }^{6} \mathrm{H}_{9 / 2}$ bands are smaller. In $\mathrm{BaSm}_{2}\left(\mathrm{MoO}_{4}\right)_{4}$, the ${ }^{4} \mathrm{G}_{5 / 2} \rightarrow{ }^{6} \mathrm{H}_{5 / 2}$ transition, in difference with glasses, is the smallest, while ${ }^{4} \mathrm{G}_{5 / 2}$ $\rightarrow{ }^{6} \mathrm{H}_{9 / 2}$ is the strongest one, and ${ }^{4} \mathrm{G}_{5 / 2} \rightarrow{ }^{6} \mathrm{H}_{9 / 2}$ is slightly weaker, but of a comparable amplitude. ${ }^{4} \mathrm{G}_{5 / 2} \rightarrow{ }^{6} \mathrm{H}_{11 / 2}$ transition, being typically the smallest of all in glasses, is also observed in $\mathrm{BaSm}_{2}\left(\mathrm{MoO}_{4}\right)_{4}$ (not shown in Fig. 6), but its magnitude is close to the noise level, while, in the reference crystal, it was not detected at all. The potential energy minimum attained under the crystal structure formation is deeper than in case of glassy state, and it is governed by the interactions within the crystal unit cell, i.e. at larger distances than in glass. The peculiarities described above indicate that the role of crystal structure in the formation of $\mathrm{Sm}^{3+}$ local environment is very high in the reference crystal structure; however, in the $\mathrm{BaSm}_{2}\left(\mathrm{MoO}_{4}\right)_{4}$ crystal, the matrix influence is also noticeable in comparison with glassy ones. Another noteworthy feature is the absence of 
luminescent bands from the states higher than ${ }^{4} \mathrm{G}_{5 / 2}$ in $\mathrm{BaSm}_{2}\left(\mathrm{MoO}_{4}\right)_{4}$. These bands are well seen in the reference crystal, and that indicates the stronger radiativeless relaxation from the higher-lying states to ${ }^{4} \mathrm{G}_{5 / 2}$ in $\mathrm{BaSm}_{2}\left(\mathrm{MoO}_{4}\right)_{4}$ than that in $\beta-\mathrm{RbSm}\left(\mathrm{MoO}_{4}\right)_{2}$. One of these states is ${ }^{4} \mathrm{I}_{9 / 2}$, that produces the well detectable luminescence in the blue range in $\beta-\mathrm{RbSm}\left(\mathrm{MoO}_{4}\right)_{2}$ when excited at $355 \mathrm{~nm}$. This level, however, can be directly excited by the $488 \mathrm{~nm}$ radiation. We have tested this excitation channel and have found that the luminescence spectrum under the $488 \mathrm{~nm}$ excitation is in a close agreement with that excited at $355 \mathrm{~nm}$. The main difference is the weak band intensity increase above $700 \mathrm{~nm}$ due to the ${ }^{4} \mathrm{G}_{5 / 2} \rightarrow{ }^{6} \mathrm{H}_{11 / 2}$ transition and the minor redistribution of crystalfield-split components intensities within ${ }^{4} \mathrm{G}_{5 / 2} \rightarrow{ }^{6} \mathrm{H}_{9 / 2}$ band, while ${ }^{4} \mathrm{G}_{5 / 2} \rightarrow{ }^{6} \mathrm{H}_{5 / 2}$ and ${ }^{4} \mathrm{G}_{5 / 2} \rightarrow{ }^{6} \mathrm{H}_{7 / 2}$ bands are almost untouched by the excitation wavelength change. The observed differences indicate a fine variation of population distribution between ${ }^{4} \mathrm{G}_{5 / 2}$ components at the $488 \mathrm{~nm}$ excitation with respect to the $355 \mathrm{~nm}$ excitation.

\section{Conclusions}

In the present work, binary molybdate $\mathrm{BaSm}_{2}\left(\mathrm{MoO}_{4}\right)_{4}$ was successfully synthesized by the ceramic method. The crystal structure and spectroscopic characteristics were exhibited for the first time. The structure is layered and the interlayer distance is controlled by the size of $\mathrm{Ba}^{2+}$ ion. This specific geometry provides the highly anisotropic behavior of the cell parameters on the substitution of $\mathrm{Sm}^{3+}$ by other rare earth ions. As an example, the comparison of the presently-known cell parameters in monoclinic $\mathrm{BaSm}_{2}\left(\mathrm{MoO}_{4}\right)_{4}, \mathrm{BaNd}_{2}\left(\mathrm{MoO}_{4}\right)_{4}$ and $\mathrm{BaYb}_{2}\left(\mathrm{MoO}_{4}\right)_{4}$ possesses noticeable variation of $a$ and $b$ parameters and a very small variation of the $c$ parameter. This specific structural feature may be an indicator of high anisotropy of physical properties, including thermal, optical and dielectric parameters. Testing the effects is the challenge for the nearest future, when the single crystals of the molybdates from this family will be available. The luminescence spectra of $\mathrm{Sm}^{3+}$ ions, which are positioned in the lowest local symmetry site $\mathrm{C}_{1}$, strongly differ from those detected for another molybdate crystal, $\beta$ - $\operatorname{RbSm}\left(\mathrm{MoO}_{4}\right)_{2}$, with the $\mathrm{C}_{2}$ local symmetry. The ${ }^{4} \mathrm{G}_{5 / 2} \rightarrow$ 
${ }^{6} \mathrm{H}_{9 / 2}$ band is dominating in the $\mathrm{BaSm}_{2}\left(\mathrm{MoO}_{4}\right)_{4}$ luminescence. These features demonstrate the possibilities of controlling the luminescent spectra by the crystal design in new molybdate families.

\section{Acknowledgements}

This work was supported by the National Natural Science Foundation of China (U1632146). The reported study was funded by RFBR according to the research projects $16-52-48010$, 16-3200351 and 17-52-53031. Also, the work was supported by (Act 211) the Government of the Russian Federation, contract 02.A03.21.0011, by Project № 0356-2015-0412 of SB RAS Program№II.2P, and by the Ministry of Education and Science of the Russian Federation (4.1346.2017/PP). 


\section{References}

1. Pinglu Shi, Zhiguo Xia, M.S. Molokeev, V.V. Atuchin, Crystal chemistry and luminescence properties of red-emitting $\mathrm{CsGd}_{1-\mathrm{x}} \mathrm{Eu}_{\mathrm{x}}\left(\mathrm{MoO}_{4}\right)_{2}$ solid-solution phosphors, Dalton Trans. 43 (2014) 9669-9676.

2. Wentao Zhang, Junfeng Li, Yulong Wang, Jianping Long, Kehui Qiu, Synthesis and luminescence properties of $\mathrm{NaLa}\left(\mathrm{MoO}_{4}\right)_{2-\mathrm{x}} \mathrm{AG}_{\mathrm{x}}: \mathrm{Eu}^{3+}\left(\mathrm{AG}=\mathrm{SO}_{4}{ }^{2-}, \mathrm{BO}_{3}{ }^{3-}\right)$ red phosphors for white light emitting diodes, J. Alloys Compd. 635 (2015) 16-20.

3. Huajuan Deng, Ze Zhao, Jing Wang, Zhoufei Hei, Mengxue Li, Hyeon MiNoh, Jung HyunJeong, RuijinYu, Photoluminescence properties of a new orange-red emitting $\mathrm{Sm}^{3+}$-doped $\mathrm{Y}_{2} \mathrm{Mo}_{4} \mathrm{O}_{15}$ phosphor, J. Solid State Chem. 228 (2015) 110-116.

4. M. Janulevicius, J. Grigorjevaite, G. Merkininkaite, S. Sakirzanovas, A. Katelnikovas, Luminescence and luminescence quenching of $\mathrm{Eu}_{2} \mathrm{Mo}_{4} \mathrm{O}_{15}$, J. Lumin. 179 (2016) 35-39.

5. Yun Liu, Jinyang Li Haoqiang Zuo, Xiaolei Shi, Suiyan Ma, Minzhu Zhao, Synthesis and luminescent properties of $\mathrm{KLa}_{1-\mathrm{x}-\mathrm{y}}\left(\mathrm{MoO}_{4}\right)_{2-\mathrm{z}}\left(\mathrm{WO}_{4}\right)_{\mathrm{z}}: \mathrm{xEu}^{3+}, \mathrm{yDy}^{3+}$ phosphors for WLEDs, J. Mater. Sci.: Mater. Electron. 27 (2016) 9470-9475.

6. Jing Li, Li Chen, Jiahua Zhang, Zhendong Hao, Yongshi Luo, Ligong Zhang, Photoluminescence properties of a novel red-emitting phosphor $\mathrm{Eu}^{3+}$ activated scandium molybdate for white light emitting diodes, Mat. Res. Bull. 83 (2016) 290-293.

7. Dong-ni Wu, Xin-yong Gong, Rui-rui Cui, Chao-yong Deng, Luminescence properties of $\mathrm{Ca}^{2+}$ and $\mathrm{Si}^{4+}$ co-doped strontium molybdate red phosphors for white LEDs, J. Mater. Sci.: Mater. Electron. 27 (2016) 9661-9667.

8. V. Mahalingam, M. Syed Gulam Ambia, J. Thirumalai, R. Krishnan, R. Chandramohan, Spectroscopic investigations of $\mathrm{Sm}^{3+}$ doped $\mathrm{Ca}_{0.5} \mathrm{La}\left(\mathrm{MoO}_{4}\right)_{2}$ phosphor for solid state lighting applications, J. Mater. Sci.: Mater. Electron. 28 (2017) 2838-2845. 
9. Chang Sung Lim, V. Atuchin, A. Aleksandrovsky, M. Molokeev, A. Oreshonkov, Microwave sol-gel synthesis of $\mathrm{CaGd}_{2}\left(\mathrm{MoO}_{4}\right)_{4}: \mathrm{Er}^{3+} / \mathrm{Yb}^{3+}$ phosphors and their upconversion photoluminescence properties, J. Am. Ceram. Soc. 98 (2015) 3223-3230.

10. Chang Sung Lim, A. S. Aleksandrovsky, M. S. Molokeev, A. S. Oreshonkov, D. A. Ikonnikov, V. V. Atuchin, Triple molybdate scheelite-type upconversion phosphor $\mathrm{NaCaLa}\left(\mathrm{MoO}_{4}\right)_{3}: \mathrm{Er}^{3+} / \mathrm{Yb}^{3+}$ structural and spectroscopic properties, Dalton Trans. 45 (2016) $15541-15551$.

11. Li-Qiang Mai, Fan Yang, Yun-Long Zhao, Xu Xu, Lin $\mathrm{Xu}$, \& Yan-Zhu Luo, Hierarchical $\mathrm{MnMoO}_{4} / \mathrm{CoMoO}_{4}$ heterostructured nanowires with enhanced supercapacitor performance, Nature Comm. 2:381 (2011) 2-5.

12. Di Zhou, Li-Xia Pang, Jing Guo, Ying Wu, Gao-Qun Zhang, Wei Dai, Hong Wang, Xi Yao, New microwave dielectric ceramics $\mathrm{BaLn}_{2}\left(\mathrm{MoO}_{4}\right)_{4}(\mathrm{Ln}=\mathrm{Nd}$ and Sm) with low loss, J. Am. Ceram. Soc. 94 (2011) 2800-2803.

13. Wen-Bo Li, Hai-Hong Xi, Di Zhou, Microwave dielectric properties of temperature-stable $\mathrm{BaLn}_{2}\left(\mathrm{MoO}_{4}\right)_{4}-\mathrm{TiO}_{2}(\mathrm{Ln}=\mathrm{Ce}, \mathrm{Nd}$, and Sm) ceramics, J. Elect. Mater. 44 (11) (2015) 42504254.

14. Li-Xia Pang, Wei-Guo Liu, Di Zhou, Zhen-Xing Yue, Phase evolution and microwave dielectric properties of $\left(\mathrm{Bi}_{1-\mathrm{x}} \mathrm{Ln}_{\mathrm{x}}\right)_{2} \mathrm{MoO}_{6}(\mathrm{Ln}=\mathrm{Nd}$ and $\mathrm{La}, \mathrm{x} \leq 0.3)$ ceramics, Ceram. Int. 42 (2016) $17243-17247$.

15. P. Hongda Li, Wenjun Li, Shaonan Gu, Fangzhi Wang, Hualei Zhou, Xintong Liu, Chaojun Ren, Enhancement of photocatalytic activity in $\mathrm{Tb} / \mathrm{Eu}$ co-doped $\mathrm{Bi}_{2} \mathrm{MoO}_{6}$ : the synergistic effect of Tb-Eu redox cycles, RSC Adv. 6 (2016) 48089-48098.

16. F. Namvar, F. Beshkar, M. Salavati-Niasari, S. Bagheri, Morphology-controlled synthesis, characterization and photocatalytic property of hierarchical flower-like $\mathrm{Dy}_{2} \mathrm{Mo}_{3} \mathrm{O}_{9}$ nanostructures, J. Mater. Sci.: Mater. Electron. (2017) DOI 10.1007/s 10854-017-6799-4. 
17. A. V. Lebedev, S. A. Avanesov, Barium-bismuth molybdate - a novel promising material for stimulated Raman scattering, Mater. Lett. 161 (2015) 661-664.

18. Yang Zhang, Hengjiang Cong, Huaidong Jiang, Jing Li, Jiyang Wang, Flux growth, structure, and physical characterization of new disordered laser crystal $\mathrm{LiNd}\left(\mathrm{MoO}_{4}\right)_{2}$, J. Cryst. Growth $423(2015) 1-8$.

19. A.M. Abakumov, V,A, Morozov, A.A. Tsirlin, J. Verbeeck, J. Hadermann, Cation ordering and flexibility of the $\mathrm{BO}_{4}{ }^{2-}$ tetrahedra in incommensurately modulated $\mathrm{CaEu}_{2}\left(\mathrm{BO}_{4}\right)_{4}(\mathrm{~B}=\mathrm{Mo}, \mathrm{W})$ scheelites, Inorg. Chem. 53 (2014) 9407-9415.

20. G.D. Tsyrenova, E.T. Pavlova, S.F. Solodovnikov, N.N. Popova, T.Y. Kardash, S.Y. Stefanovich, I.A. Gudkova, Z.A. Solodovnikova, B.I. Lazoryak, New ferroelastic $\mathrm{K}_{2} \mathrm{Sr}\left(\mathrm{MoO}_{4}\right)_{2}$ : synthesis, phase transitions, crystal and domain structure, ionic conductivity, J. Solid State Chem. 237 (2016) 64-71.

21. Chang Sung Lim, V.V. Atuchin, A.S. Aleksandrovsky, M.S. Molokeev, A.S. Oreshonkov, Incommensurately modulated structure and spectroscopic properties of $\mathrm{CaGd}_{2}\left(\mathrm{MoO}_{4}\right)_{3}: \mathrm{Ho}^{3+} / \mathrm{Yb}^{3+}$ phosphors for up-conversion applications, J. Alloys Compd. 695 (2017) 737-746.

22. S.F. Solodovnikov, V.V. Atuchin, Z.A. Solodovnikova, O.Y. Khyzhun, M.I. Danilenko, D.P. Pishchur, P.E. Plusnin, A.M. Pugachev, T.A. Gavrilova, A.P. Yeliseeyev, Ali H. Reshak, Zeyad A. Alahmed, Nadir F. Habubi, Synthesis, structural, thermal, and electronic properties of palmierite-related double molybdate $\alpha-\mathrm{Cs}_{2} \mathrm{~Pb}\left(\mathrm{MoO}_{4}\right)_{2}$, Inorg. Chem. 56 (6) (2017) 3276-3286.

23. V. V. Atuchin, A. S. Aleksandrovsky, O. D. Chimitova, T. A. Gavrilova, A. S. Krylov, M. S. Molokeev, A. S. Oreshonkov, B. G. Bazarov, J. G. Bazarova, Synthesis and spectroscopic properties of monoclinic $\alpha-\mathrm{Eu}_{2}\left(\mathrm{MoO}_{4}\right)_{3}$, J. Phys. Chem. C 118 (2014) 15404-15411.

24. Ali H. Reshak, Z.A. Alahmed, J. Bila, V.V. Atuchin, B.G. Bazarov, O.D. Chimitova, M.S. Molokeev, I.P. Prosvirin, A.P. Yelisseyev, Exploration of the electronic structure of monoclinic 
$\alpha-\mathrm{Eu}_{2}\left(\mathrm{MoO}_{4}\right)_{3}$ : DFT-based study and X-ray photoelectron spectroscopy, J. Phys. Chem. C 120 (2016) 10559-10568.

25. I. I. Kiseleva, M. I. Sirota, R. P.Ozerov, T. P.Balakireva, A. A.Majer, Double barium lanthanide molibdates $\mathrm{BaLn}_{2}\left(\mathrm{MoO}_{4}\right)_{4}$. Kristallografiya, 24(6), 1979, 1277-1279.

26. A.V. Malakhovskii, T.V. Kutsak, A.L. Sukharev, A.S. Aleksandrovsky, A.S. Krylov, I.A. Gudim, M.S. Molokeev, Spectroscopic properties of $\mathrm{ErAl}_{3}\left(\mathrm{BO}_{3}\right)_{4}$ single crystals, Chem. Phys. 428 (2014) 137-143.

27. A.S. Krylov, S.V. Goryainov, N.M. Laptash, A.N. Vtyurin, S.V. Melnikova, S.N. Krylova, Influence of the molecular groups ordering on structural phase transitions in $\left(\mathrm{NH}_{4}\right)_{2} \mathrm{WO}_{2} \mathrm{~F}_{4}$, Cryst. Growth Des. 14 (1) (2014) 374-380.

28. Peter A. Jansson, Deconvolution with applications in spectroscopy - Academic Press, 1984.

29. Bruker AXS TOPAS V4: General profile and structure analysis software for powder diffraction data. - User's Manual. Bruker AXS, Karlsruhe, Germany. 2008.

30. St. Gallinat, H. Müller-Buschbaum, Zwei Beispiele für partielle and totale Defekte im $\mathrm{Ba} \mathrm{Ln}_{2} \mathrm{Mo}_{4} \mathrm{O}_{16}$-Typ: $\mathrm{BaCu}_{0.41} \mathbf{m}_{0.59} \mathrm{Pr}_{2} \mathrm{Mo}_{4} \mathrm{O}_{16}$ und $\mathrm{Ba} \mathrm{Yb}_{2} \mathrm{Mo}_{4} \mathrm{O}_{16}, \mathrm{Z}$. Naturforsch. B 51 (1) (1996) 85-89.

31. I.B. Troitskaia, T.A. Gavrilova, S.A. Gromilov, D.V. Sheglov, V.V. Atuchin, R.S. Vemuri, C.V. Ramana, Growth and structural properties of $\alpha-\mathrm{MoO}_{3}(010)$ microplates with atomically flat surface, Mater. Sci. Eng. B 174 (1-3) (2010) 159-163.

32. V.V. Atuchin, T.A. Gavrilova, T.I. Grigorieva, N.V. Kuratieva, K.A. Okotrub, N.V. Pervukhina, N.V. Surovtsev, Sublimation growth and vibrational microspectrometry of $\alpha-\mathrm{MoO}_{3}$ single crystals, J. Cryst. Growth 318 (2011) 987-990.

33. M. Buijs, G. Blasse, Nonresonant energy transfer in a system with two different rare-earth sites: $\beta^{\prime}-\mathrm{Gd}_{2}\left(\mathrm{MoO}_{4}\right)_{3}: \mathrm{Eu}^{3+}$ and $\beta^{\prime}-\mathrm{Eu}_{2}\left(\mathrm{MoO}_{4}\right)_{3}$, Phys. Rev. B 34 (12) (1986) 8815-8821.

34. J. Hanuza, L. Macalik, K. Hermanowicz, Vibrational properties of $\mathrm{KLn}\left(\mathrm{MoO}_{4}\right)_{2}$ crystals for light rare earth ions from lanthanum to terbium, J. Mol. Struct. 319 (1994) 17-30. 
35. L. Macalik, Comparison of the spectroscopic and crystallographic data of $\mathrm{Tm}^{3+}$ in the different hosts: $\mathrm{KLn}\left(\mathrm{MoO}_{4}\right)_{2}$ where $\mathrm{Ln}=\mathrm{Y}, \mathrm{La}, \mathrm{Lu}$ and $\mathrm{M}=\mathrm{Mo}$, W, J. Alloys Compd. 341 (2002) 226232.

36. V. Dmitriev, V. Sinitsyn, R. Dilanian, D. Machon, A. Kuznetsov, E. Ponyatovsky, G. Lucazeau, H.P. Weber, In situ pressure-induced solid-state amorphization in $\mathrm{Sm}_{2}\left(\mathrm{MoO}_{4}\right)_{3}, \mathrm{Eu}_{2}\left(\mathrm{MoO}_{4}\right)_{3}$ and $\mathrm{Gd}_{2}\left(\mathrm{MoO}_{4}\right)_{3}$ crystals: chemical decomposition scenario, J. Phys. Chem. Solids 64 (2003) 307312.

37. V.V. Atuchin, O.D. Chimitova, T.A. Gavrilova, M.S. Molokeev, Sung-Jin Kim, N.V. Surovtsev, B.G. Bazarov, Synthesis, structural and vibrational properties of microcrystalline $\operatorname{RbNd}\left(\mathrm{MoO}_{4}\right)_{2}$, J. Cryst. Growth 318 (2011) 683-686.

38. V.V. Atuchin, V.G. Grossman, S.V. Adichtchev, N.V. Surovtsev, T.A. Gavrilova, B.G. Bazarov, Structural and vibrational properties of microcrystalline $\mathrm{TlM}\left(\mathrm{MoO}_{4}\right)_{2}(\mathrm{M}=\mathrm{Nd}, \mathrm{Pr})$ molybdates, Opt. Mater. 34 (2012) 812-816.

39. M. Maczka, A.G. Souza Filho, W. Paraguassu, P.T.C. Freire, J. Mendes Filho, J. Hanuza, Pressure-induced structural phase transitions and amorphozation in selected molybdates and tungstates, Prog. Mater. Sci. 57 (2012) 1335-1381.

40. V.V. Atuchin, O.D. Chimitova, S.V. Adichtchev, B.G. Bazarov, T.A. Gavrilova, M.S. Molokeev, N.V. Surovtsev, Zh.G. Bazarova, Synthesis, structural and vibrational properties of microcrystalline $\beta-\mathrm{RbSm}\left(\mathrm{MoO}_{4}\right)_{2}$, Mater. Lett. 106 (2013) 26-29.

41. V.V. Atuchin, A.S. Aleksandrovsky, O.D. Chimitova, A.S. Krylov, M.S. Molokeev, B.G. Bazarov, J.G. Bazarova, Zhiguo Xia, Synthesis and spectroscopic properties of multiferroic $\beta^{\prime}-$ $\mathrm{Tb}_{2}\left(\mathrm{MoO}_{4}\right)_{3}$, Opt. Mater. 36 (2014) 1631-1635.

42. M.B. Smirnov, V.Yu. Kazimirov, LADY: software for lattice dynamics simulations. (JINR communications), E 14-2001-159, 2001.

43. M. Smirnov, R. Baddour-Hadjean, Li intercalation in $\mathrm{TiO}_{2}$ anatase: Raman spectroscopy and lattice dynamic studies, J. Chem. Phys.121 (2004) 2348-2355. 
44. A.N. Vtyurin, A.S. Krylov, S.N. Krylova, S.V. Goryainov, V.N. Voronov, A.S. Oreshonkov, Hydrostatic pressure-induced phase transitions in $\mathrm{Rb}_{2} \mathrm{KInF}_{6}$ and $\mathrm{Rb}_{2} \mathrm{KScF}_{6}$ crystals: Raman spectra and lattice dynamics simulations, Ferroelectrics 440 (2012)100-104.

45. A.S. Krylov, A.N. Vtyurin, A.S. Oreshonkov, V.N. Voronov, S.N. Krylova, Structural transformations in a single-crystal $\mathrm{Rb}_{2} \mathrm{NaYF}_{6}$ : Raman scattering study, J. Raman Spectr., 44 (2013) 763-769.

46. Y.V. Gerasimova, A.S. Oreshonkov, A.N. Vtyurin, A.A. Ivanenko, L.I. Isaenko, A.A. Ershov, E.I. Pogoreltsev,Infrared absorption investigation of the role of octahedral groups upon the phase transition in the $\mathrm{Rb}_{2} \mathrm{KMoO}_{3} \mathrm{~F}_{3}$ crystal, Phys. Solid State 55 (2013) 2331-2334.

47. Zhiguo Xia, M.S. Molokeev, A.S. Oreshonkov, V.V. Atuchin, Ru-Shi Liu, Cheng Dong, Crystal and local structure refinement in $\mathrm{Ca}_{2} \mathrm{Al}_{3} \mathrm{O}_{6} \mathrm{~F}$ explored by $\mathrm{X}$-ray diffraction and Raman spectroscopy, Phys. Chem. Chem. Phys. 16 (2014) 5952-5957.

48. A.A. Savina, V.V. Atuchin, S.F. Solodovnikov, Z.A. Solodovnikova, A.S. Krylov, E.A. Maximovskiy, M.S. Molokeev, A.S Oreshonkov, A.M. Pugachev, E.G. Khaikina, Synthesis, structural and spectroscopic properties of acentric triple molybdate $\mathrm{Cs}_{2} \mathrm{NaBi}\left(\mathrm{MoO}_{4}\right)_{3}$, J. Solid State Chem. 225 (2015) 53-58.

49. C.S. Lim, A.S. Aleksandrovsky, M.S. Molokeev, A.S. Oreshonkov, V.V. Atuchin, The modulated structure and frequency upconversion properties of $\mathrm{CaLa}_{2}\left(\mathrm{MoO}_{4}\right)_{4}: \mathrm{Ho}^{3+} / \mathrm{Yb}^{3+}$ phosphors prepared by microwave synthesis, Phys. Chem. Chem. Phys. 17 (2015) 19278-19287.

50. C.S. Lim, A. Aleksandrovsky, M. Molokeev, A. Oreshonkov, V. Atuchin, Microwave solgel synthesis and upconversion photoluminescence properties of $\mathrm{CaGd}_{2}\left(\mathrm{WO}_{4}\right)_{4}: \mathrm{Er}^{3+} / \mathrm{Yb}^{3+}$ phosphors with incommensurately modulated structure, J. Solid State Chem. 228 (2015) 160166. 
51. A.S. Oreshonkov, J.V. Gerasimova, A.A. Ershov, A.S. Krylov, K.A. Shaykhutdinov, A.N. Vtyrin, M.S. Molokeev, K.Y. Terent'ev, N.V. Mihashenok, Raman spectra and phase composition of $\mathrm{MnGeO}_{3}$ crystals, J. Raman Spectr. 47 (2016) 531-536.

52. A.S. Oreshonkov, A.S. Krylov, N.P. Shestakov, V.N. Voronov, A.A. Ershov, E.A. Strikina, A.N. Vtyurin, Vibrational spectra of $\mathrm{NdF}_{3}$ crystal, Ferroelectrics 501 (2016) 15-19.

53. E.A. Strikina, A.S. Krylov, A.S. Oreshonkov, A.N. Vtyurin, Raman scattering study of $\delta$ $\mathrm{BiB}_{3} \mathrm{O}_{6}$ crystal, Ferroelectrics 501 (2016) 26-31.

54. E.A. Strikina, A.S. Krylov, A.S. Oreshonkov, A.N. Vtyurin, O.A. Maximova, Anisotropic crystal of the $\delta-\mathrm{BiB}_{3} \mathrm{O}_{6}$ investigated by vibrational spectroscopy, IOP Conf. Ser.: Mater. Sci. Eng. 155 (2016) 012029.

55. A.S. Krylov, M.S. Molokeev, S.V. Misyul, S.N. Krylova, A.S. Oreshonkov, A.A. Ivanenko, V.A. Zykova, Y.N. Ivanov, A.A. Sukhovsky, V.N. Voronov, I.N. Safonov, A.N. Vtyurin, Crystal structure and phase transitions of layered perovskite-like $\mathrm{CsScF}_{4}$ crystal, CrystEngComm, 18 (2016) 8472-8486.

56. Y.V. Gerasimova, A.S. Oreshonkov, O.B. Romanova, A.A. Ivanenko, A.S. Krylov, Spectr. Lett. 50 (2017) 55-58.

57. Yu.V. Gerasimova, A.S. Oreshonkov, N.M. Laptash, A.N. Vtyurin, A.S. Krylov, N.P. Shestakov, A.A. Ershov, A.G. Kocharova, Raman and infrared spectroscopic characterization of gadolinium-doped manganese sulfide, Spectrochim. Acta A 176 (2017) 106-113.

58. K. Nakamoto, Infrared and Raman Spectra of Inorganic and Coordination Compounds, 6th edn. Wiley, New York etc., 2009.

59. J. Hanuza, E.B. Burgina, G.A. Osipov, E.N. Yurchenko, The low temperature spectra and normal coordinate analysis of $\mathrm{KY}\left(\mathrm{MoO}_{4}\right)_{2}$ crystal, J. Mol. Struct. 158 (1987) 141-152.

60. V. V. Atuchin, A. S. Aleksandrovsky, O. D. Chimitova, Cheng-Peng Diao, T. A. Gavrilova, V. G. Kesler, M. S. Molokeev, A. S. Krylov, B. G. Bazarov, G. Bazarova, Zheshuai Lin, Electronic 
structure of $\beta-\mathrm{RbSm}\left(\mathrm{MoO}_{4}\right)_{2}$ and chemical bonding in molybdates, Dalton Trans. 44 (2016) 1805-1815.

61. R. Van Deun, K. Binnemans, C. Gorler-Walrand, J.L.Adam, Spectroscopic properties of trivalent samarium ions in glasses, Proc. SPIE 3622 (1999) 175-181. 
Table 1. Main parameters of processing and refinement of the $\mathrm{BaSm}_{2}\left(\mathrm{MoO}_{4}\right)_{4}$ sample

\begin{tabular}{cc}
\hline Compound & $\mathrm{BaSm}_{2}\left(\mathrm{MoO}_{4}\right)_{4}$ \\
\hline Sp.Gr. & $C 2 / c$ \\
$a, \AA$ & $5.29448(5)$ \\
$b, \AA$ & $12.7232(1)$ \\
$c, \AA$ & $19.3907(2)$ \\
$\beta,^{\circ}$ & $91.2812(6)$ \\
$V, \AA^{3}$ & $1305.89(2)$ \\
$Z$ & 4 \\
$2 \theta$-interval, & $5-140$ \\
$R_{w p}, \%$ & 2.26 \\
$R_{p}, \%$ & 1.95 \\
$R_{\text {exp }}, \%$ & 1.36 \\
$\chi^{2}$ & 1.66 \\
$R_{B}, \%$ & 1.01 \\
\hline
\end{tabular}


Table 2. Calculated wavenumber versus experimental relative magnitude $(I)$, wavenumber and full width at half maximum (FWHM) of the Raman lines

\begin{tabular}{|c|c|c|c|c|}
\hline \multicolumn{2}{|c|}{$\omega, \mathrm{cm}^{-1}$ (calc.) } & \multirow[t]{2}{*}{$I$, (exp.) } & \multirow{2}{*}{$\begin{array}{c}\omega, \mathrm{cm}^{-1} \\
\text { (exp.) }\end{array}$} & \multirow{2}{*}{$\begin{array}{c}\Gamma(\mathrm{FWHM}), \\
\mathrm{cm}^{-1}\end{array}$} \\
\hline$A_{g}$ & $B_{g}$ & & & \\
\hline 950.1 & 946.4 & 100 & 950.2 & 3.2 \\
\hline \multirow{2}{*}{925.1} & \multirow{2}{*}{924.3} & 2.4 & 929.1 & 1.9 \\
\hline & & 29.7 & 925.3 & 3.4 \\
\hline \multirow{2}{*}{886.0} & \multirow{2}{*}{889.8} & 12.8 & 890.4 & 4.7 \\
\hline & & 3.4 & 883.0 & 6.1 \\
\hline 847.6 & 847.0 & 71.4 & 854.6 & 8.3 \\
\hline 820.4 & 820.4 & 1.5 & 840.8 & 30.3 \\
\hline 802.7 & 802.6 & 3.8 & 799.8 & 9.8 \\
\hline 750.5 & 750.7 & 9.2 & 753.0 & 9.5 \\
\hline \multirow{2}{*}{704.8} & \multirow{2}{*}{705.7} & 4.1 & 713.3 & 11.0 \\
\hline & & 0.3 & 702.5 & 11.2 \\
\hline \multicolumn{5}{|l|}{499.7} \\
\hline \multirow[t]{2}{*}{418.4} & & 1.2 & 417.7 & 7.6 \\
\hline & 407.3 & 2.8 & 406.1 & 8.1 \\
\hline \multirow{2}{*}{381.6} & \multirow{2}{*}{380.4} & 5.5 & 394.9 & 10.9 \\
\hline & & 1.7 & 383.4 & 8.62 \\
\hline 365.3 & 364.2 & \multirow{2}{*}{5.3} & \multirow{2}{*}{361.4} & \multirow{2}{*}{6.5} \\
\hline 354.5 & 355.7 & & & \\
\hline 339.4 & 343.2 & 10.8 & 345.0 & 11.8 \\
\hline \multirow{2}{*}{320.0} & \multirow{2}{*}{319.5} & 28.0 & 322.1 & 9.7 \\
\hline & & 2.9 & 313.0 & 6.1 \\
\hline 299.0 & 306.6 & 13 & 2077 & 100 \\
\hline 297.4 & 294.6 & 1.3 & 291.1 & 10.0 \\
\hline 288.3 & 285.9 & 1.0 & 280.7 & 9.7 \\
\hline \multirow{2}{*}{271.2} & 274.6 & \multirow{2}{*}{1.1} & \multirow{2}{*}{269.0} & \multirow{2}{*}{9.1} \\
\hline & 263.9 & & & \\
\hline 253.8 & & 0.03 & 252.6 & 7.4 \\
\hline & 253.4 & 0.3 & 244.5 & 9.4 \\
\hline 227.9 & & 2.5 & 225.6 & 10.3 \\
\hline 206.8 & 213.9 & 0.01 & 211.6 & 2.6 \\
\hline 195.1 & 199.6 & 3.2 & 181.9 & 6.3 \\
\hline 172.2 & 166.3 & 5.1 & 161.1 & 5.1 \\
\hline 153.9 & 155.6 & 1.5 & 155.9 & 4.7 \\
\hline 142.0 & 141.8 & 18.9 & 145.9 & 4.8 \\
\hline 139.1 & & 8.5 & 139.0 & 4.8 \\
\hline & 134.2 & 3.0 & 132.8 & 3.5 \\
\hline 123.2 & 122.8 & 4.1 & 127.3 & 4.1 \\
\hline 120.4 & 114.1 & 3.4 & 118.2 & 3.4 \\
\hline & 113.3 & 3.0 & 113.7 & 3.5 \\
\hline 103.4 & & 16.5 & 108.7 & 2.7 \\
\hline & 102.2 & 2.9 & 101.5 & 3.8 \\
\hline 93.9 & 89.6 & 0.6 & 94.8 & 1.2 \\
\hline 85.7 & 81.5 & 9.9 & 83.8 & 3.0 \\
\hline 736 & 78.1 & 38 & 738 & 25 \\
\hline & 67.6 & & & \\
\hline 48.7 & 48.2 & 10.6 & 49.0 & 2.4 \\
\hline
\end{tabular}




\section{Captions}

Fig 1. Difference Rietveld plot of $\mathrm{BaSm}_{2}\left(\mathrm{MoO}_{4}\right)_{4}$.

Fig. 2. Crystal structure of $\mathrm{BaSm}_{2}\left(\mathrm{MoO}_{4}\right)_{4}$. The unit cell is outlined. The lone atoms of Sm, Mo and $\mathrm{O}$ are omitted for clarity.

Fig. 3. SEM pattern of the $\mathrm{BaSm}_{2}\left(\mathrm{MoO}_{4}\right)_{4}$ microcrystals.

Fig. 4. Raman spectrum of $\mathrm{BaSm}_{2}\left(\mathrm{MoO}_{4}\right)_{4}$.

Fig. 5. Calculated vibration modes of the $\mathrm{MoO}_{4}$ tetrahedrons in $\mathrm{BaSm}_{2}\left(\mathrm{MoO}_{4}\right)_{4}$. a) $A_{\mathrm{g}} 950.1 \mathrm{~cm}^{-1}$, b) $A_{\mathrm{g}} 886.0 \mathrm{~cm}^{-1}$, c) $A_{\mathrm{g}} 847.6 \mathrm{~cm}^{-1}$, d) $A_{\mathrm{g}} 704.8 \mathrm{~cm}^{-1}$, e) $A_{\mathrm{g}} 499.6 \mathrm{~cm}^{-1}$.

Fig. 6. Luminescence spectra of $\mathrm{BaSm}_{2}\left(\mathrm{MoO}_{4}\right)_{4}$ (thick red) and $\beta-\mathrm{RbSm}\left(\mathrm{MoO}_{4}\right)_{2}$ (thin blue) excited at $355 \mathrm{~nm}$.

Fig. 7. Local environment of $\mathrm{Sm}^{3+}$ ion in $\mathrm{BaSm}_{2}\left(\mathrm{MoO}_{4}\right)_{4}$ (left) and $\beta-\mathrm{RbSm}\left(\mathrm{MoO}_{4}\right)_{2}$ (right) crystal structures. 


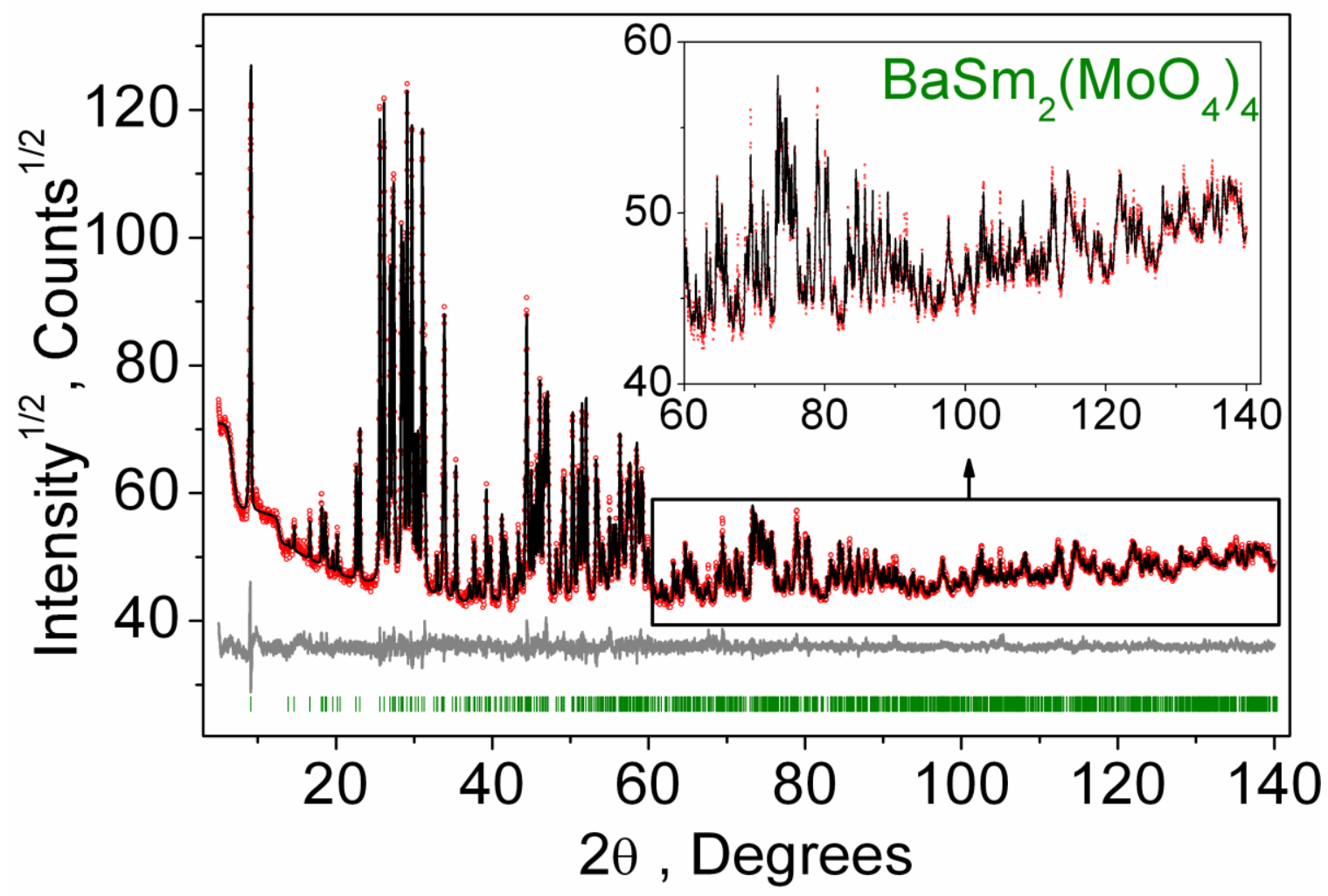

Figure 1. 


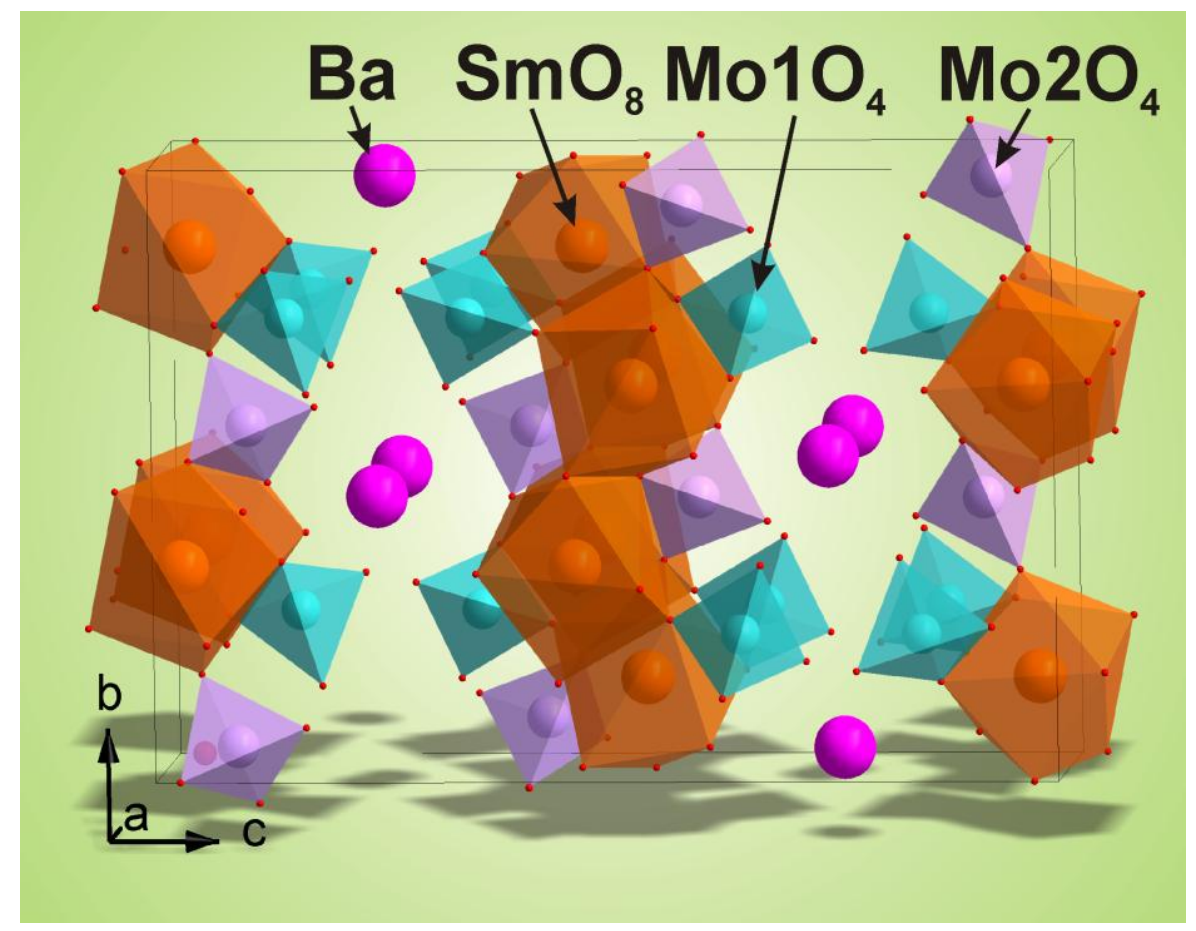

Figure 2. 


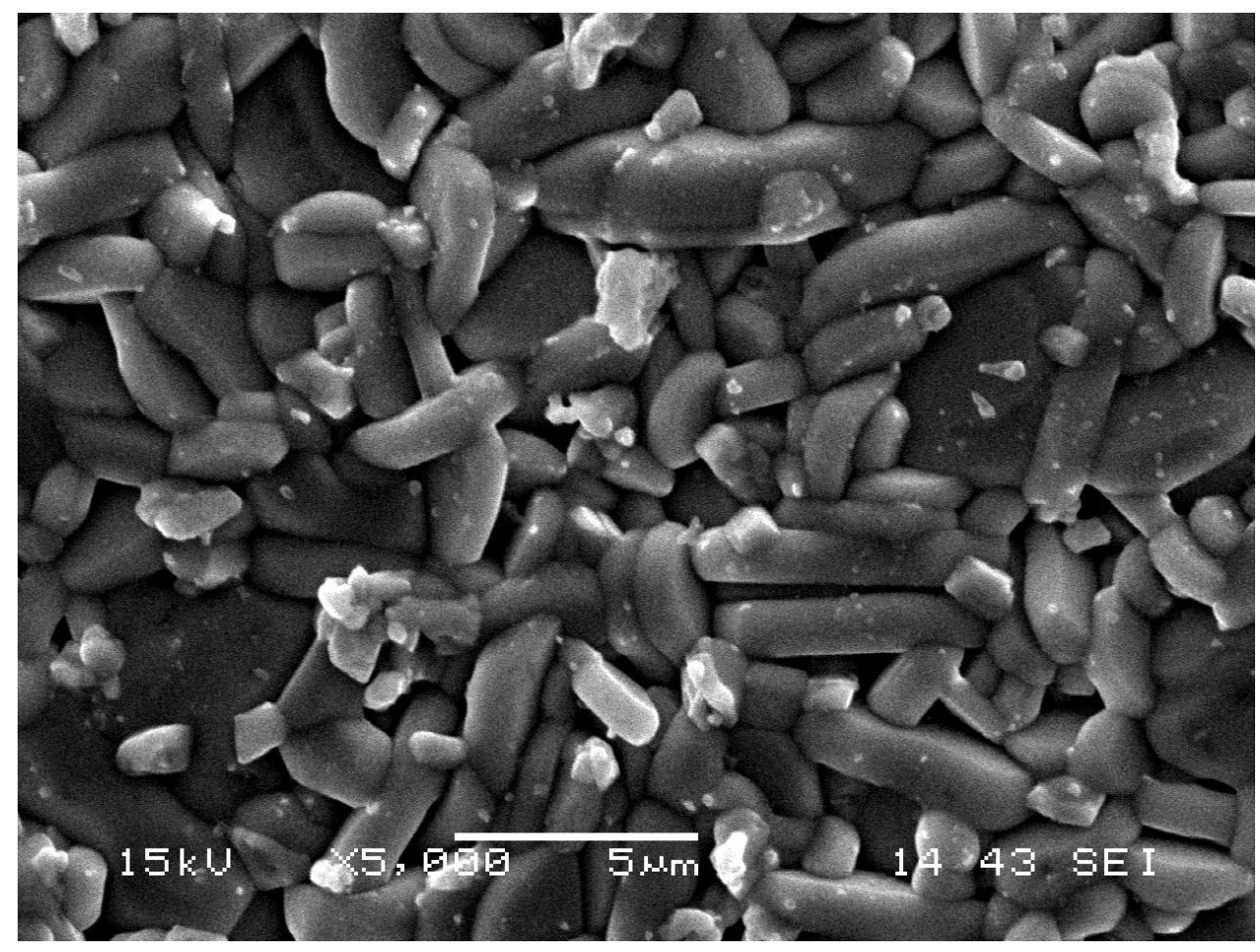

Figure 3. 


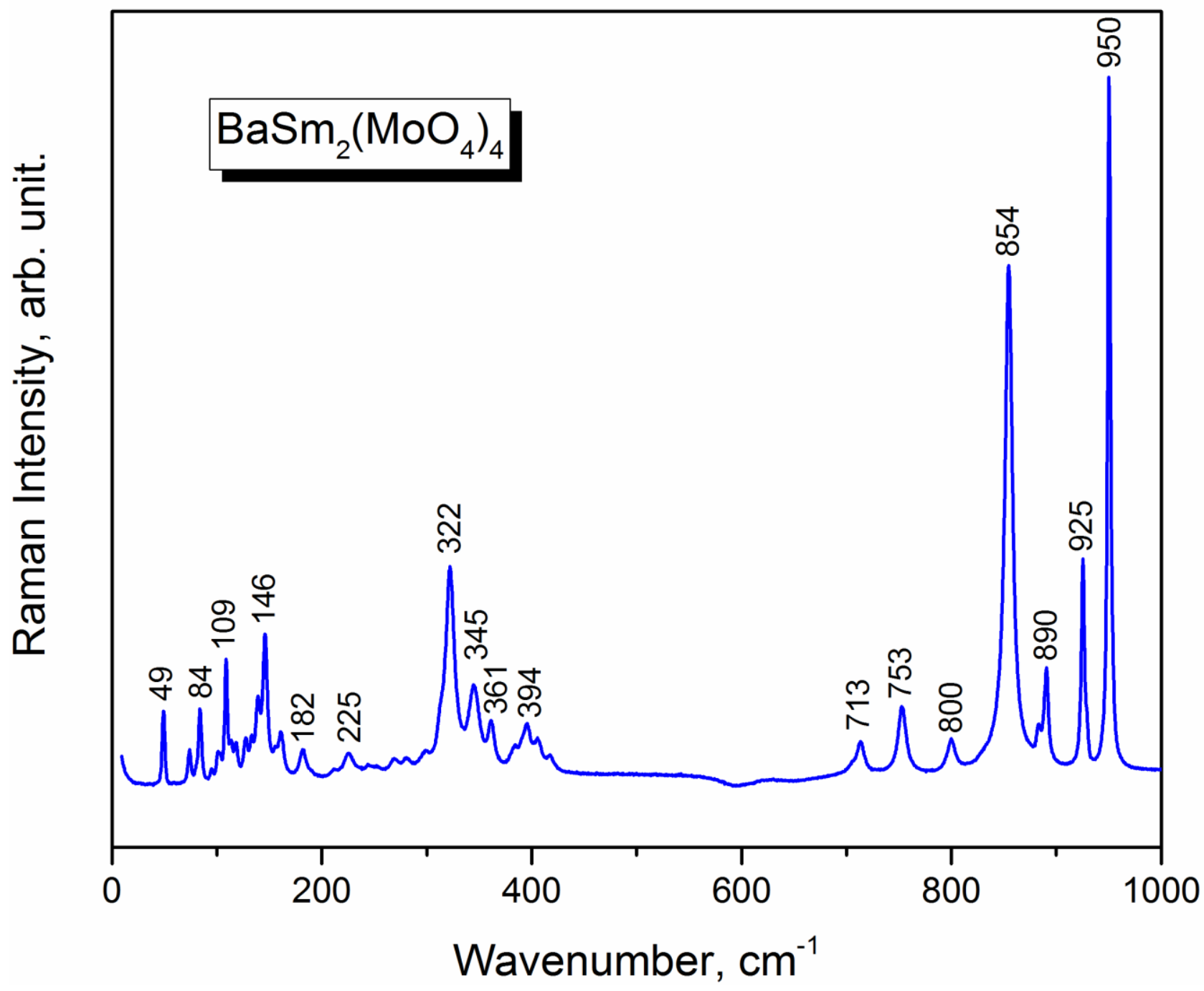

Figure 4. 

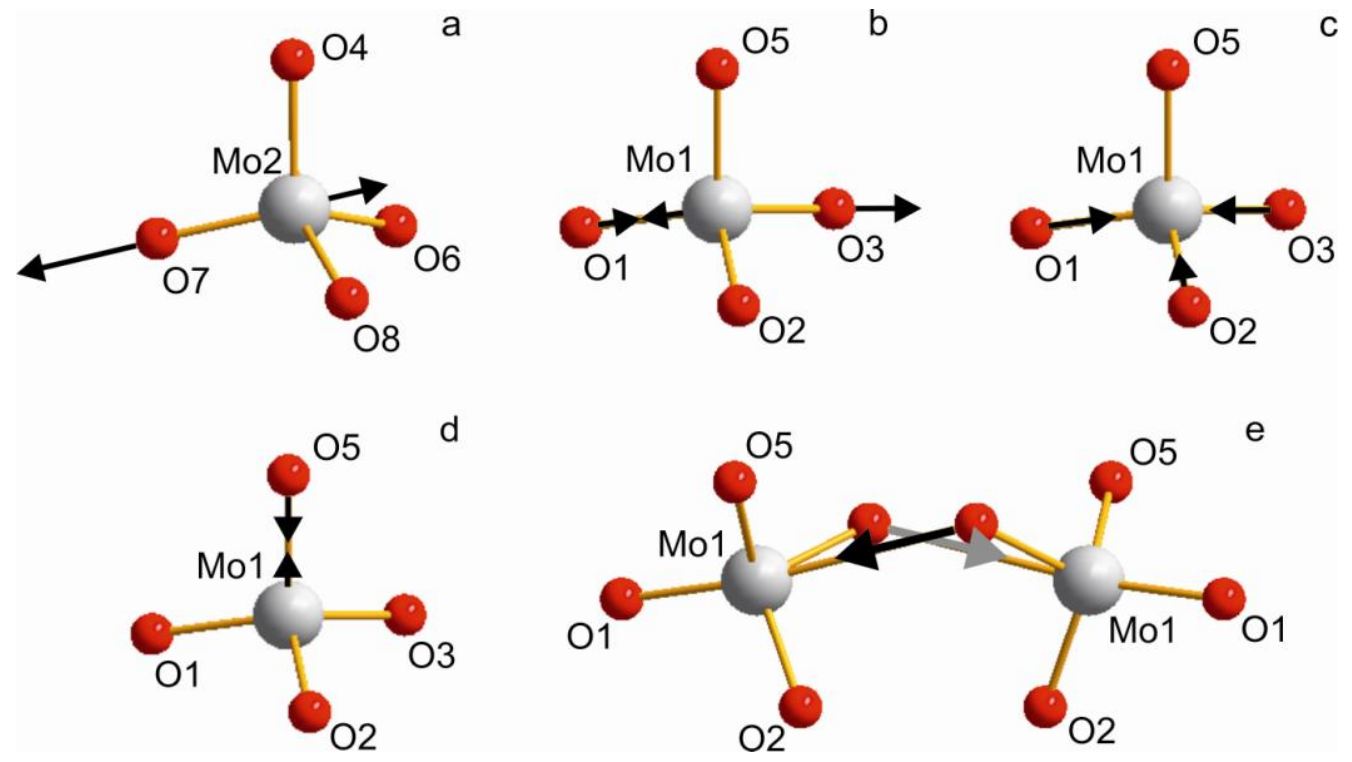

Figure 5. 


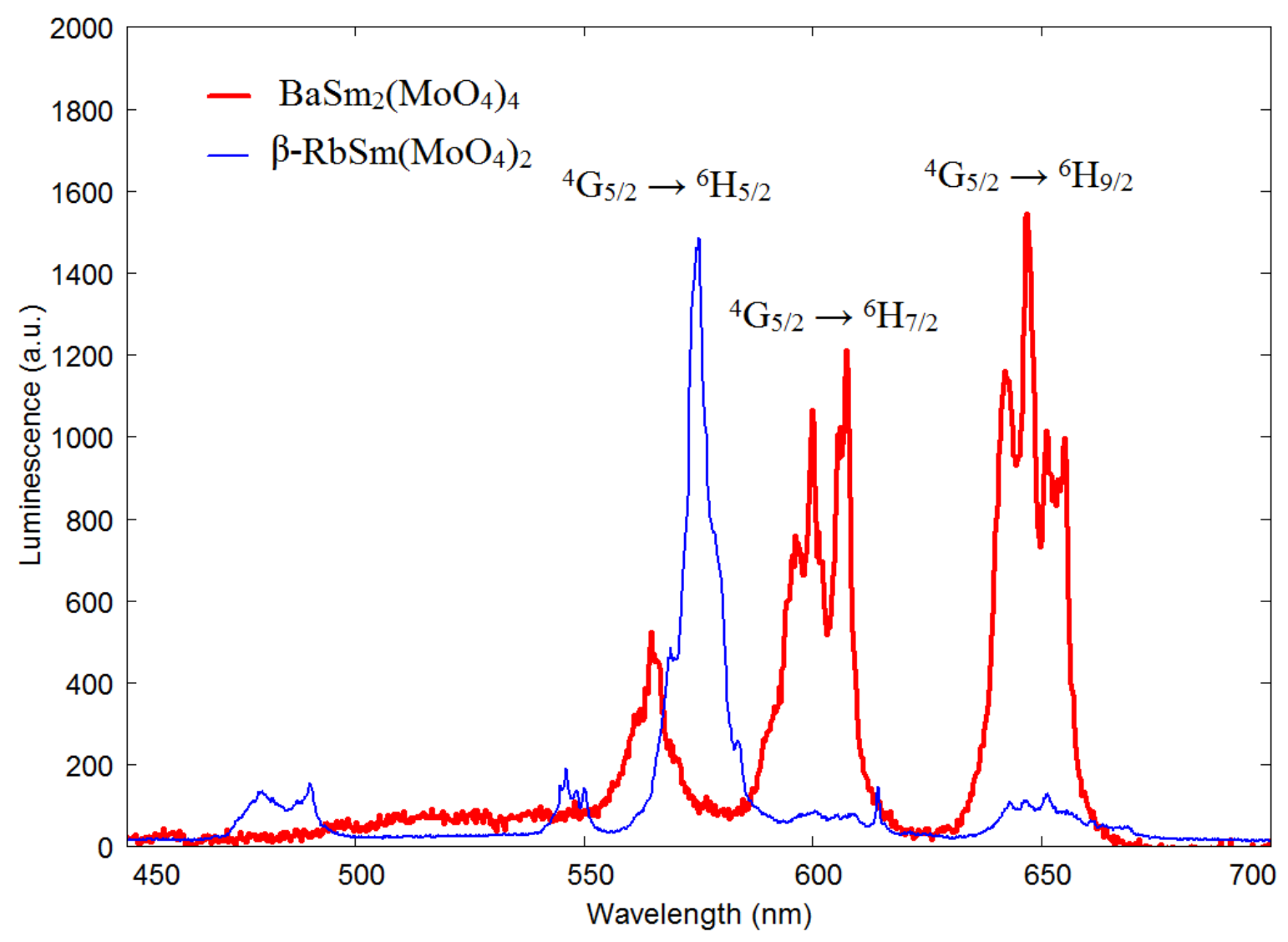

Figure 6. 


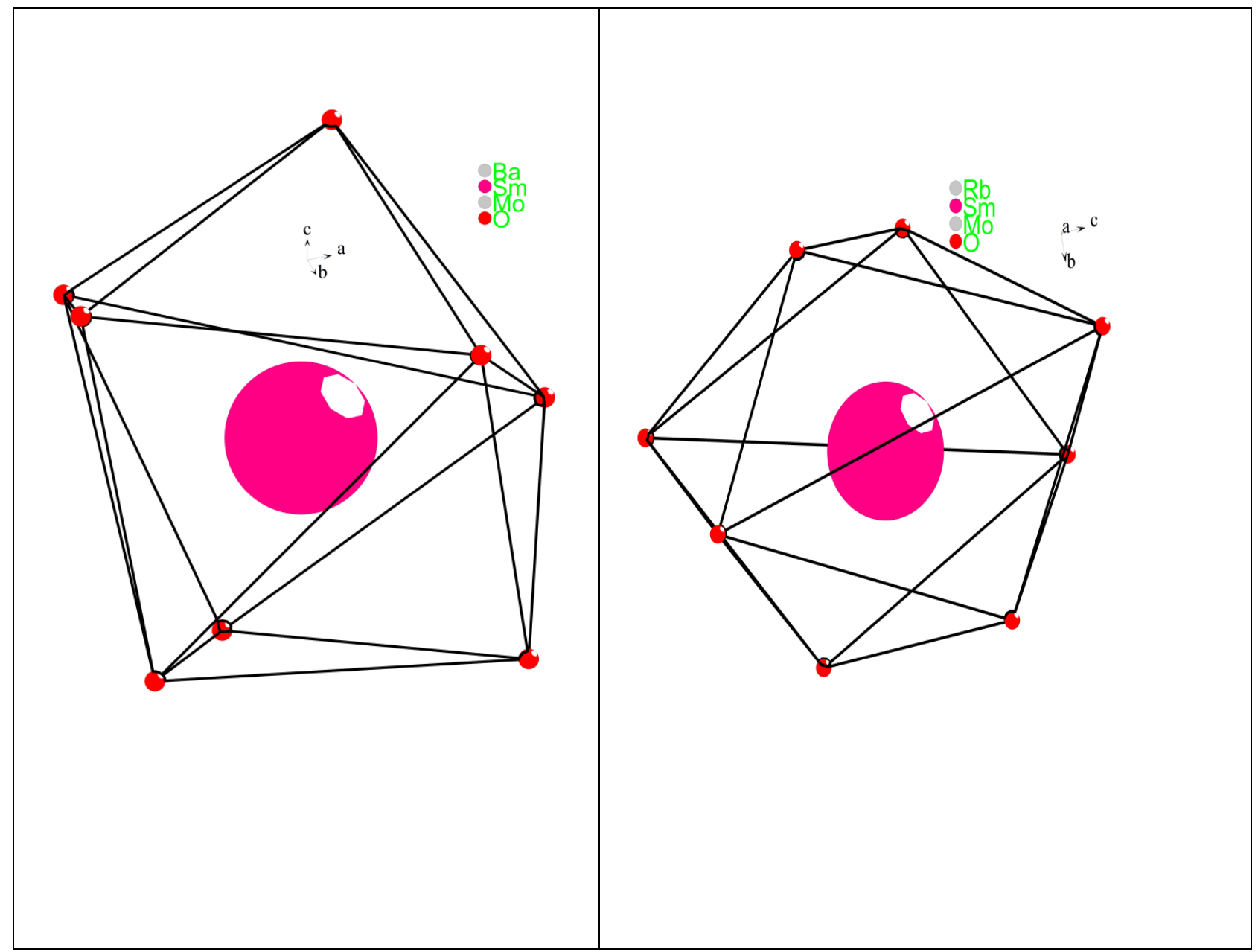

Figure 7. 